\title{
'Menunggu Godot' \\ Peradilan HAM dan Tanggung Jawab TNI
}

\author{
Eko Prasetyo
}

The emerging of Human Rights Court particularly for the Indonesian National Army, the myths regarding patriotic and war should be disarmed and the responsibility should be carried out. In this context, the norm of human right prepares an effective service for those who become the victims of naive nationalism or stability in appearance. Practising of responsibility stated above has large implication, namely choosing the action of security must consider four important factors: (1) whether the action aforementioned is in accordance with law, (2) is it proportionally?, (3) is it coincide with the ethics?, and (4) that the action is really needed and accepted by society. According to writer that described four considerations must be guidance, instead, it needed to be organization formulation so that they do not motivate the Indonesian National Army return to dark eras.

Mereka yang memerangi rakyat untuk menghentikan kebebasan dan Hak Asasi Manusia harus dilawan bukan sebagai musuh biasa, tetapi sebagai pembunuh dan bandit pemberontak

(Robespierre)

Barangkali kita tidak pernah menyangka, ia duduk di depan majelis hakim untuk kasus yang nilainya sepadan, dengan apa yang terjadi pada masa Hitler. Dengan baju seragam dan dukungan dari beberapa petinggi militer, sejumlah aparat kepolisian dan TNI, kini diadili oleh Peradilan HAM yang ada di Jakarta. Dakwaan yang ditimpakan pada mereka, cukup serius dan berat, yakni kejahatan terhadap kemanusiaan. Kejahatan yang dulu dengan angkuh dilakukan untuk menjaga stabilitas dan keamanan, terbukti telah memakan nyawa banyak warga sipil yang tidak berdosa. Begitulah, dalam terjemahan HAM, kejahatan terhadap kemanusiaan tergolong merupakan pelanggaran HAM berat. Dan itu sama dengan yang sekarang ini, didakwakan oleh Mahkamah Pidana International, yang berkedudukan di Belanda, terhadap seorang mantan penguasa sekaligus penjagal, yakni Slobodan Milosevic, mantan pemimpin Yugoslavia. Begitulah nasib muram yang menimpa beberapa

'Waiting for Godot merupakan naskah paling terkenal dari Samuel Beckeet, seorang penulis naskah dan novelis dari Irlandia. Pengenalan dan pementasan naskah Waiting for Godot ini mengacu pada tafsiran dari (lingkaran) Rendra yang dijuluki, Menunggu Godot. Kisah ini bercerita tentang perjalanan hidup dua orang sahabat, Vladimir dan Estagon yang menantikan kehadiran seorang Godot, di pinggir jalan dekat sebuah pohon. Penantian Godot yang panjang hingga kemudian datang berita bahwa Godot tidak datang, dikemas oleh Beckett dengan bahasa yang suram. Penulis kutip cerita ini untuk menunjukkan betapa lama menunggu vonis bagi para Jenderal yang jelas telah membunuhi rakyat, bahkan Peradilan HAM pun yang konon menjanjikan keadilan, seperti sosok Godot. Lih Beckett, Samuel., Sementara Menunggu Godot, Tarawang, 1999. 
jendral yang dulu pernah jaya kini musti duduk sebagai pesakitan di kursi terdakwa pelanggaran berat HAM. Di atas kursi yang berhadapan muka dengan majelis hakim HAM ad hoc itu wajah kesatuan militer dipertaruhkan dan namanya peradilan di Indonesia, selalu terbuka banyak kemungkinan atas hasilnya. Sebuah vonis hukuman bisa jatuh atau bisa jadi putusan bebas, yang mungkin oleh kalangan masyarakat, sudah tidak lagi mengejutkan.

Karena itu sejumlah nama-nama yang masih memegang jabatan datang pada hari pertama pengadilan HAM ad hoc ini. Di negeri dimana militer menghuni banyak posisi tentu kedatangan mereka ke ruang sidang adalah pertunjukan besar. Beberapa jenderal yang diajukan sebagai saksi, mulai menyebut jasa dan peran tentara dalam meredam konflik di Timor-Timur. Mereka malah mengandaikan bila militer tidak hadir sudah pasti akan terjadi bentrokan yang jauh lebih besar. Di tengah kematian banyak penduduk mungkin pembelaan itu terasa janggal dan menyedihkan. Semua tahu Timor Timur adalah koloni Indonesia, yang tidak pernah diakui oleh masyarakat International. Dari segi ini, bisa dikatakan kekerasan yang dilakukan oleh Militer sama persis dengan apa yang dikerjakan oleh pasukan Slobodan ketika membunuhi etnis Bosnia. Maka, tiada jalan pertanggung-jawaban lain kecuali melalui Peradilan HAM ad hoc, karena membayangkan peradilan umum, makin sulit untuk dicari deliknya. Melalui peradilan HAM mithos mengenai patriotisme dan peperangan harus dilucuti sekaligus dimintai pertanggung-jawaban. Norma Hak Azasi Manusia menyediakan pelayanan efektif bagi mereka yang selama ini sering jadi korban Nasionalisme yang naif atau stabilitas keamanan yang semu.

Tetapi, semua percaya, militer adalah kekuatan yang memiliki segala pengaruh dan terlanjur melakukan tindakan yang mencemarkan. Jika bicara soal kekejaman di negeri ini, dapat dikatakan militer ambil peran terbesar, dari penculikan, penyiksaan hingga pembunuhan. Di masa lalu kegiatan sadis ini bisa berlindung di bawah atap persatuan dan stabilitas. Saat ini, melalui kaidah hukum HAM, segala tindakan aparat negara harus dipertanggung-jawabkan secara hukum. Norma HAM dibentuk memang untuk memerangi segala tindakan yang melecehkan martabat kemanusiaan, dan penghormatan pada HAM, akan menuntut pengusutan atas semua kasus kekejaman yang terjadi di masa lalu. Negara, dalam kaitan dengan sistem hukum HAM memang dibebani kewajiban untuk menghormati semua kaidah-kaidah HAM. ${ }^{2}$ Makin besar wewenang yang dipunyai oleh aparat negara, akan makin menguat pula, kontrol atas penggunaan wewenangnya. Sarana kelembagaan yang tersedia, yakni Peradilan HAM diharapkan mampu menembus batas 'impunity' atau kekebalan yang biasanya melekat pada setiap tindakan aparat. Payung ideologis TNI

${ }^{2}$ Dalam sistem hukum HAM terdapat ketentuan sebagai berikut: Pertama menempatkan negara sebagai aktor utama yang memegang kewajiban dan tanggung jawab (duty holders). Sementara individu (termasuk juga kelompok dan "rakyat") berkedudukan sebagai pemegang hak (right holders). Kedua, Negara dalam system hak asasi manusia dengan demikian tidak memiliki hak; kepadanya hanya dipikulkan kewajiban atau tanggung jawab (obligation atau responsibility) untuk memenuhi hak-hak (yang dimiliki individu atau kelompok) yang dijamin dalam instrumen-instrumen tersebut. Ketiga jika negara tidak mau atau tidak punya keinginan memenuhi kewajibanya itu, maka disinilah negara tersebut dapat dikatakan telah melakukan pelanggaran hak asasi manusia atau hukum International. Apabila pelanggaran tersebut tidak mau mau dipertanggungjawabkan oleh negara, maka tanggung jawab itu akan diambil alih oleh masyarakat international. Lih Kasim, Ifdhal., 2001, "Perintah Global Menegakkan Hak Asasi Manusia", dalam Instrumen Pokok Hak Asasi Manusia International Bagi Aparatur Penegak Hukum, Jakarta: Elsam. 
yakni dwi fungsi akan menjadi tantangan sendiri bagi upaya penegakan Peradilan HAM yang serius dan konsekuen. Kini Peradilan HAM sedang melangsungkan prosesnya dan tulisan ini hendak menyorot, sejauh mana jangkauan keadilan mampu menyentuh lapis kekuasaan TNI, yang masih memiliki kuasa dan pengaruh yang besar. Kuasa yang muncul bukan semata-mata karena peluang politik tetapi juga karena dukungan sekaligus dorongan dari para politisi sipil.

\section{Arkeologi Kekerasan}

Serdadu seperti belati, tak dirawat, tumpul dan berkarat (Iwan Fals, Serdadu)

Awal mulanya memang terjadi penolakan keras ketika para Jendral mendapat panggilan untuk urusan pelanggaran HAM atas kasus Tri Sakti dan Semanggi. Seperti biasa, mereka menyatakan langkah banyak kalangan, termasuk Komnas HAM dan KPP HAM, itu melangkahi prosedur. Lebih lanjut, kalangan TNI menyatakan bahwa dalam UU Peradilan HAM No 26/200o tidak dikenal institusi yang namanya KPP HAM. ${ }^{3}$ Penolakan itu makin mengeras, ketika TNI hanya mau tunduk pada 'putusan politik' DPR yang menyatakan bahwa kasus Tri Sakti dan Semanggi cukup diselesaikan melalui Peradilan Umum dan Peradilan Militer. Resiko perlawanan itu sah-sah saja, namun yang keterlaluan adalah, cara argumentasi tim hukum TNI yang sangat tekstual dan kurang memahami pemberlakuan asaz-asaz hukum Hak Asazi Manusia. Mereka terlalu menyakini dan bersikeras bahwa semua tindakan yang dilakukan oleh Komnas HAM maupun KPP HAM hanya digunakan untuk menyudutkan posisi TNI saja. Sementara itu, kalangan TNI lupa, bahwa untuk memulai perbaikan pada bangsa ini, salah satunya yang perlu diubah, adalah cara pandang mereka sendiri terhadap persoalan.

Tepatnya, TNI melalui sistem hukum HAM dimintai pertanggung-jawaban atas semua kebijakannya. Mengingat dalam sistem hukum HAM, TNI selaku aparat negara mendapat beban dan tanggung jawab sebagai pemegang kewajiban. 4 Kaidah 'pemegang kewajiban yang secara otomatis berarti tidak punya hak' sulit untuk dijelaskan menurut kerangka pikir TNI. Terlalu lama TNI hidup dalam kultur politik yang otoriter dan sangat luas wewenang yang dipunyainya. TNI yang memiliki argumentasi mithologis, yakni pembela dan pejuang kemerdekaan, secara tidak terelakkan mempunyai 'hak' untuk memperlakukan apa saja terhadap rakyat negeri ini. Perlakuan 'apa saja' ini dapat ditafsirkan melalui dikeluarkanya berbagai

3Sebut saja argumen kuasa hukum TNI Kolonel AB Setiawan yang menyebutkan bahwa dalam UU Pengadilan HAM No 26 tahun 2000 tidak dikenal institusi yang namanya KPP HAM, tetapi argumen ini secara sosiologis kurang kuat, karena selama ini KPP HAM telah banyak membentuk tim ad hoc, seperti KPP HAM Timor Timur, KPP HAM Tanjung Priok dan KPP HAM Abepura dan tidak pernah TNI menolak panggilan KPP HAM tersebut. Persepsi mereka pada kasus Tri Sakti dan Semanggi hanya berlandaskan pada 'keputusan politik' DPR yang menyatakan kasus itu bukan pelanggaran berat HAM. Padahal ini hanya pemanggilan yang belum tentu bermuara ke Pengadilan, karena harus disaring dulu oleh DPR dan Kejaksaan Agung. Penolakan ini memang' sangat ironis di tengah keinginan hendak menegakkan system Peradilan HAM. Lih Kompas 20 Febr 2002.

4Pertanggung jawaban negara dalam system hukum HAM biasanya dilihat dalam tiga bentuk. Yang pertama adalah menghormati (obligation to respect), yang kedua melindungi (obligation to protect) sementara yang terakhir adalah dalam bentuk pemenuhan (obligation
to fulfil). Ibid h.viii. 
produk hukum yang dalam pelbagai bentuknya, mengukuhkan kembali kontrol militer terhadap masyarakat sipil. Kontrol ini dijelmakan melalui penciptaan lembaga maupun dikeluarkannya produk hukum; misalnya pada sisi kelembagaan muncul institusi militer yang merasuk hingga ke tingkat desa, dari Kodem, Korem hingga Babinsa. Sedangkan dalam kaitannya dengan produk hukum, terdapat puluhan aturan yang mengingkari asaz demokrasi, salah satu yang kini telah dicabut, adalah UU Subversif. Aturan inilah yang sering menjadi dasar legal bagi semua tindakan kekerasan, seperti yang terjadi pada masa Orde Lama. Tetapi pertanyaannya, apakah aturan semata-mata yang memunculkan kekerasan. Terhadap jawaban pertanyaan diatas, muncul sederet analisia.

Charles Tilly menyatakan, yang mendasari munculnya pranata kekerasan, satu diantara yang terpenting, adalah pertumbuhan negara itu sendiri. Gagasan mengenai negara, seperti yang dinyatakan oleh Charles Tilly, erat kaitanya dengan munculnya kekerasan. Dalam pertumbuhanya negara memang memulai aktivitasnya lewat penciptaan perang yang mana tujuan utama adalah perluasan, pemusnahan maupun menetralisasikan lawan-lawan yang berada di luar wilayah teritorialnya. Secara brutal misalnya TNI melakukan penyerbuan, penyiksaan hingga pembunuhan warga Timor-Timur dan hal yang sama dilakukan untuk penduduk sipil yang berada di Aceh serta Papua. Penciptaan negara kesatuan yang dulu memayungi banyak propinsi, memberikan peran yang besar dan luas, pada dipakainya cara-cara kekerasan. Ditunjang dengan kebijakan teritorial seperti pembentukan institusi militer yang pararel dengan institusi sipil maka militer betul-betul ingin membangun tatanan yang pretoria. Pretoria adalah situasi yang mengacu pada peran tentara untuk tampil sebagai aktor politik utama yang sangat dominan dengan menggunakan atau memanfaatkan kekuasaan yang dipunyai. Dalam praktek pengaruh ini kemudian menyebar luas dalam institusi dalam TNI itu sendiri.

Hannah Arendt menyatakan kekerasan muncul juga karena tabiat institusi. Paparanya tentang siapa pelaku kekerasan selalu dikaitkan dengan budaya kelembagaan yang tidak demokratis dan cenderung otoriter. Arendt mengamati prilaku kekerasan biasanya didapati pada seorang yang hanya patuh secara membabi buta, miskin inisiatif dan tidak memiliki imajinasi. Sosok yang berkarakter seperti ini akan memandang wajar perlakuan yang berbeda terhadap kelompok lain. Karena kelompok lain itu berbeda, maka patut untuk diperlakukan secara lebih buruk bahkan bisa juga dengan cara yang sadis. Tindakan kekerasan akan gampang muncul pada pribadi semacam ini, karena tidak pernah mampu memaknai tindakan. Ia hidup dalam institusi yang memakan habis propaganda dan ditanamkan pikiran untuk memihak atau melawan sesuatu. Moralitas pragmatis ini, yang kerapkali muncul dalam peryataan-peryataan TNI, ketika membela diri atas tindakan kekerasan yang dilakukanya. Merasa bahwa sebagai aparat 'penting' negara, maka ditempuhnya tindak kekerasan, justru untuk mengamankan kekuasaan dari ancaman pihak lain. Ekspresi tindakan itulah, yang kerapkali muncul lewat penyiksaan yang beraneka ragam bentuknya. Pada kenyataanya institusi TNI yang tidak menggunakan kultur demokrasi akan membawa aparaturnya pada tindakan yang naif bahkan terbukti membawa TNI pada citra sebagai lembaga yang penuh dengan praktek korupsi, melalui yayasan-yayasan yang dimilikinya. Dalam tabel 1 membuktikan bagaimana korupsi telah merambah secara luas pada semua yayasan yang dipunyai oleh TNI.

Tentu saja intitusi bukanlah aktor tunggal yang menyulut kekerasan, ada faktor sampingan lain, di antaranya adalah 


\section{Tabel 1. Penyimpangan di Yayasan-yayasan TNI dan Polri}

\begin{tabular}{|c|c|c|c|c|}
\hline & Nama Yayasan & $\begin{array}{l}\text { Jenis } \\
\text { Pelanggaran }\end{array}$ & $\begin{array}{c}\text { Nilai } \\
\text { Kerugian }\end{array}$ & Keterangan \\
\hline \multirow[t]{3}{*}{$\begin{array}{l}\text { Dephan } \\
\text { dan Mabes }\end{array}$} & $\begin{array}{l}\text { Yayasan } \\
\text { Kejuangan } \\
\text { Panglima Besar. } \\
\text { Sudirman }\end{array}$ & & & \\
\hline & $\begin{array}{l}\text { Yayasa Satya } \\
\text { Bhakti Pertiwi }\end{array}$ & & & \\
\hline & $\begin{array}{l}\text { Yayasan } \\
\text { Markas Besar } \\
\text { ABRI (Yamabr) }\end{array}$ & $\begin{array}{l}\text { Merugikan } \\
\text { Negara }\end{array}$ & $\begin{array}{l}23,436 \\
\text { Miliar }\end{array}$ & $\begin{array}{l}\text { Pemasukan Badan Pengelola Balai Sudirman (BPBS) } \\
\text { yang berlokasi di tanah negara tidak disetor ke Kas } \\
\text { Negara }\end{array}$ \\
\hline \multirow[t]{6}{*}{ TNI-AD } & $\begin{array}{l}\text { Yayasan Kartika } \\
\text { Eka Paksi } \\
\text { (YKEP) }\end{array}$ & $\begin{array}{l}\text { Merugikan } \\
\text { Yayasan }\end{array}$ & $\begin{array}{l}48,093 \\
\text { Miliar }\end{array}$ & $\begin{array}{l}\text { Ketua umum YKFP mengehtarkan uang tanpa } \\
\text { pertanggung jawaban }\end{array}$ \\
\hline & & $\begin{array}{l}\text { Merugikan } \\
\text { Yayasan }\end{array}$ & $\begin{array}{l}10,892 \\
\text { Miliar }\end{array}$ & $\begin{array}{l}\text { Ada utang perusahaan lain yang dibebankan ke YKEP } \\
\text { dan piutang YKEP belum tertagih }\end{array}$ \\
\hline & $\begin{array}{l}\text { Yayasan } \\
\text { Dharma Putra } \\
\text { Kostrad (YDKP) }\end{array}$ & $\begin{array}{l}\text { Pengeluaran } \\
\text { tidak sertai } \\
\text { bukti }\end{array}$ & 29 Miliar & $\begin{array}{l}\text { Pengadaan barang, tanah, dan renovasi banguran, yang } \\
\text { seharusnya dilakukan sejak Jamuari } 2000 \text { behum } \\
\text { dilaksanakan }\end{array}$ \\
\hline & & $\begin{array}{l}\text { Pembukuan } \\
\text { yang tidak } \\
\text { berar }\end{array}$ & $\begin{array}{c}6,5 \\
\text { Miliar }\end{array}$ & Harga jual 50 hektare tanah yang dibayar terlahu mahal \\
\hline & $\begin{array}{l}\text { Yayasan } \\
\text { Kesejahteran } \\
\text { Kops Baret } \\
\text { Merah } \\
\text { (Kobame) }\end{array}$ & $\begin{array}{l}\text { Merugikan } \\
\text { Negara }\end{array}$ & $\begin{array}{l}205,437 \\
\text { Miliar }\end{array}$ & $\begin{array}{l}\text { Kobame harus membayar sejumlah besar utang yang } \\
\text { diderita perusahaan-perusahaannya di bawah dan } \\
\text { menderita piutang macet }\end{array}$ \\
\hline & & $\begin{array}{l}\text { Merugikan } \\
\text { Yayasan }\end{array}$ & $\begin{array}{l}14,023 \\
\text { Miliar }\end{array}$ & $\begin{array}{l}\text { Pengadaan rompi anti peluru dan payung udara. Ifal ini } \\
\text { tidak masuk dalam anggaran dasar Yayasan }\end{array}$ \\
\hline TNI-AL & $\begin{array}{l}\text { Yayasan } \\
\text { Bhumyamka }\end{array}$ & & & \\
\hline \multirow[t]{3}{*}{ TNI-AU } & $\begin{array}{l}\text { Yayasan Adi } \\
\text { Upaya (Yasau) }\end{array}$ & $\begin{array}{l}\text { Merugikan } \\
\text { Negara }\end{array}$ & $\begin{array}{l}9,019 \\
\text { Miliar }\end{array}$ & $\begin{array}{l}\text { Penggumaan aset negara di } 10 \text { lokasi Jakarta dan } \\
\text { Bandung seluas } 3,8 \text { juta meter persegi hingga tahun } \\
1999 \text { tidak disetor ke negara }\end{array}$ \\
\hline & & $\begin{array}{l}\text { Merugikan } \\
\text { Yayasan }\end{array}$ & $\begin{array}{l}2,372 \\
\text { Miliar }\end{array}$ & $\begin{array}{l}\text { PT Ambura Tharuma, yang mengelola aset TNI-AU di } \\
\text { Kebayoran, tidak disetor ke negara }\end{array}$ \\
\hline & & $\begin{array}{l}\text { Merugikan } \\
\text { Yayasan }\end{array}$ & $\begin{array}{l}2,372 \\
\text { Mitiar }\end{array}$ & $\begin{array}{l}\text { PT Mega Dirga Indah Bandung, pengelola aset TNI-AU } \\
\text { di Bandung, tidak penuhi setoran }\end{array}$ \\
\hline Polri & $\begin{array}{l}\text { Yayasan Brata } \\
\text { Bhakti }\end{array}$ & & . & \\
\hline
\end{tabular}

Sumber: Audit BPK yang dikutip dari Tempo 19 Nopember 2000

Ket: Kolom yang kosong menunjukkan tidak ada hasil audit yang dipaparkan 
peluang politik yang sedang berubah. Ditengarai oleh proses transisi yang sedang berlangsung disertai perebutan pada kunci posisi politik maka kekerasan bisa jadi mekanisme yang diandalkan. Kasus perusakan kantor Kontras dan pemukulan terhadap anggota UPC di Komnas HAM merupakan pola lain kekerasan. Berbeda dengan kekerasan sebelumnya, maka dua kasus tersebut, membenturkan antar masyarakat sipil. Rupanya dengan berlindung di balik, kelompok etnis atau kelompok agama, dengan gampang kekerasan disulut untuk tujuan yang seringkali naif. Tentu kejadian tersebut, tidak bisa dipisahkan dari proses perubahan politik yang memungkinkan pergesekan kepentingan antar masingmasing aktor. Kontras, kebetulan merupakan institusi yang paling gencar dalam melakukan sorotan atas pelanggaran HAM oleh TNI dan seringkali mempublikasikan temuanya ke publik. Keleluasaan Kontras jelas membahayakan dan perlawanan dilakukan untuk membatasi pengaruhnya. Tindakan yang pada akhirnya kontra produktif bahkan mengancam pertumbuhan gagasan demokrasi. Kalau bisa disebut sebuah pola, maka perusakan ini merupakan kekerasan yang muncul, karena ada ruang politik yang sedang bergeser. Kontras dan Komnas HAM merupakan elemen masyarakat sipil, yang memiliki fungsi dasar, sebagai kekuatan kontrol sekaligus penegak HAM. Pergeseran politik, tidak membuat pandangan positif pada kedua lembaga di atas, malahan yang timbul adalah kecemasan dan kekuatiran kalau kedua lembaga ini hanya akan memperlamban restorasi kekuasaan status quo.

Dalam arti ini, kritikan deras para politisi PDI-P pada beberapa LSM, menjadi semacam pertunjukan ulang penguasa Orde Baru. Dapat dikatakan, posisi politik yang kembali berada di tangan kaum konservatif, akan memandang kritik maupun saran sebagai kegiatan yang mengancam. Kecekatan kalangan politisi untuk menunda penyelesaian atas kasus pelanggaran HAM juga dapat dikategorikan sebagai cara efektif untuk menahan laju perubahan. Dengan situasi seperti ini, maka problem politik yang berbasis pada pengakuan serta perlindungan hak rakyat, beralih pada kegiatan, yang mengandalkan negosiasi antar elit. Dalam dimensi ini, lebih penting untuk mengagendakan kenaikan tarif listrik dan BBM ketimbang menyoal secara lebih serius, pelanggaran HAM yang terjadi di masa lalu. Contoh itu mengungkap kenyataan betapa banyak diantara politisi kita alam berpikirnya mengikuti irama politik yang selalu berubah-ubah. Pada satu waktu, setuju jika Timor-Timur dan Tanjung Priok diselesaikan melalui peradilan HAM sedang pada saat yang lain menolak penyelesaian yang serupa untuk kasus Tri Sakti, Semanggi I dan Semanggi II. Kebijakan yang sifatnya, menyesuaikan dengan tingkat pengaruh kursi di Parlemen ini, akan menjamin kelangsungan usia kekerasan. Dapat dirumuskan secara singkat: kekerasan muncul menjadi gejala yang umum karena ruang politik dibuka untuk itu. Bisa saja satu saat, muncul peryataan keprihatinan mendalam atas kasus kekerasan, tetapi itu bukan berarti, kasus ini lalu ditangani, ditindak-lanjuti apalagi dilakukan pengusutan secara mendalam. Menunjuk pada penyebab akhir kekerasan, maka faktor yang paling sering dari mencuatnya kasus kekerasan, adalah peluang politik yang berubah.

Dengan demikian, terbitnya UU Peradilan HAM no 26 tahun 2000, menghadapi dua tantangan penting. Pertama, pelanggaran HAM yang kemungkinan melibatkan banyak tokoh maupun lembaga yang penting akan terbentur pada sedikit-banyaknya pengaruh kekuasaan untuk ikut-campur. Ini dapat dilihat, dari tekhnik prosedural hukum pelanggaran HAM berat yang terjadi sebelum UU Peradilan HAM ini disahkan, harus melalui mekanisme yang ada dalam parlemen. Parlemen memiliki 
kuasa yang besar dan kuat, untuk menetapkan mana saja kasus yang pantas dibawa ke peradilan HAM ad hoc mana yang tidak. ${ }^{5}$ Meskipun tekanan masyarakat luas cukup kuat, tetapi jika parlemen menolak maka, tekanan itu tidak membawa hasil yang diharapkan. Dengan demikian pola penyelesaian kasus pelanggaran HAM untuk konteks Indonesia memberikan kesempatan yang luas terjadinya persekutuan antara anggota parlemen sipil dengan parlemen yang berasal dari fraksi TNI. Persoalan kedua, berkaitan dengan masih lemahnya tekanan masyarakat sipil terhadap kasus pelanggaran berat HAM. Ketika terjadi penyerangan pada aktivis HAM, sangat sedikit bahkan hampir tidak ada, masyarakat sipil yang terorganisir kemudian melancarkan tekanan protes pada negara. Sektor masyarakat sipil yang lemah dan tidak aktif ini akan membuat tidak kondusif atau terganggunya proses penegakan HAM. Hal ini yang menjadi penyebab terbesar, mudahnya kalangan elit politik untuk melakukan berbagai kompromi yang secara tidak langsung menghapus tuntutan pertanggungjawaban atas pelanggaran berat HAM.

Kondisi lain yang sangat tidak kondusif bagi penegakan HAM adalah kampanye luas pemberantasan terorisme yang terjadi di masyarakat International. TNI yang sebelumnya dipandang sebagai kekuatan penghambat demokrasi, lewat kampanye anti teroris, mendapat peluang peran yang lebih luas. Ini menyangkut misalnya, mulai dibukanya kembali perbincangan menyangkut pencabutan embargo AS kepada militer di Indonesia. 'Dulu, pada tahun 1999, karena alasan pelanggaran HAM di Timor-Timur, Kongres AS menunda bantuan dan latihan militer dengan Indonesia. Diakui oleh kalangan TNI, akibat kebijakan ini, terjadi penurunan kemampuan tempur TNI karena keterbatasan peralatan, suku cadang dan persenjataan jenis lethal weapon (senjata mematikan $)^{6}$ Efek suram dari kampanye in adalah munculnya kebutuhan untuk menerbitkan berbagai aturan perundangundangan yang mengabaikan prinsipprinsip HAM. Secara khusus mungkin ini bisa ditunjuk dari digagasnya RUU Anti Terorisme yang masih memberikan wewenang luas pada aparat keamanan untuk melakukan tindakan yang. mengabaikan HAM. Prospek penegakan hukum HAM, dalam jangka panjang, memang harus menghadapi tatanan International yang sedang bergeser. Apalagi jika merujuk kembali pada sikap AS, di bawah kepemimpinan George Bush, yang memperlakukan secara semena-mena tahanan perang Afganistan. Dengan mengabaikan prinsip-prinsip dalam hukum Jenewa, George Bush sebagai pemimpin negeri yang dijuluki 'polisi dunia', memberikan contoh terburuk dalam soal penegakan HAM. Artinya peluang penegakan HAM makin memprihatinkan di tengah tatanan masyarakat International yang lebih memilih untuk melakukan serangkaian tindakan represif, dengan alasan yang kini lagi populer, pembasmian terorisme.

5Dalam pasal 43 UU Peradilan HAM dinyatakan (1) Pelanggaran hak asasi manusia yang berat yang terjadi sebelum diundangkanya Undang-undang ini, diperiksa dan diputus oleh Pengadilan HAM ad hoc (2) Pengadilan HAM ad hoc sebagaimana dimaksud dalam ayat (1) dibentuk atas usul Dewan Perwakilan Rakyat Republik Indonesia berdasarkạn peristiwa tertentu dengan Keputusan Presiden (3) Pengadilan HAM ad hoc sebagaimana dimaksud dalam ayat (1) berada di lingkungan Peradilan Umum. Lih UU Pengadilan Hak Asasi Manusia no 26 tahun 2000.

${ }^{6} \mathrm{Lih}$ Kompas 25 April 2002. 
Pertanggungjawaban HAM dan TNI

Pemenang akan selalu menjadi hakim dan yang tertaklukkan akan senantiasa menjadi tertuduh (Herman Goering/ Tokoh Nazi)?

Nampaknya tidak terlalu lama untuk menunggu vonis Peradilan HAM, yang menurut bunyi UU Peradilan HAM, diselesaikan dalam jangka waktu 180 hari. $^{8}$ Di sidang peradilan HAM yang kini sedang digelar di Jakarta, memang muncul banyak pesimisme pada tuntutan Jaksa yang tampaknya hanya memenuhi aspek formalitas. Kasus Timor-Timur yang menelan ribuan nyawa ini memang dijadikan, alat uji awal, untuk menilai sejauh mana efektifitas yang ada dalam pasal UU Peradilan HAM dapat diterapkan.
Dalam hukum memang tidak ada perkecualian, tetapi mengingat peran serta posisi penting TNI selama ini, sangat terbuka banyak unsur yang tidak mampu dibuktikan. Tuduhan kejahatan terhadap kemanusiaan, seperti tertera dalam pasal 7 UU' Peradilan HAM, akan makin susah untuk dibuktikan jika mengingat dua aspek yang melekat pada tuduhan tersebut. Jika pembunuhan atau penyiksaan dikategorikan sebagai kejahatan terhadap kemanusiaan, maka hal yang harus dibuktikan terlebih dulu, adalah unsur sistematis dan meluas ${ }^{10}$ dari serangan itu. Ini sama artinya dengan mencoba menelusuri garis komando yang mengambil ketetapan, keputusan dan bertanggung-jawab penuh atas semua pelanggaran HAM. Di sinilah pelanggaran berat HAM dituntut untuk mengusut dan melakukan, investigasi pada institusi TNI,

\footnotetext{
'Lih, Nitibaskara, TB Ronny Rahman., Pengadilan HAM dan Masyarakat International, Kompas 20-2-2002.

${ }^{8}$ Dalam pasal 31 termuat secara jelas, perkara pelanggaran hak asasi manusia yang berat, diperiksa dan diputus oleh Pengadilan HAM dalam waktu paling lama 180 (seratus delapan puluh) hari terhitung sejak perkara dilimpahkan ke Pengadilan HAM.

'Dalam pasal 7 UU Peradilan HAM dinyatakan bahwa pelanggaran hak asasi manusia yang berat meliputi: a. Kejahatan genosida b. Kejahatan terhadap kemanusiaan. Kemudian dalam pasal 9 dinyatakan, kejahatan terhadap kemanusiaan sebagaimana dimaksud dalam pasal 7 huruf $b$ adalah salah satu perbuatan yang dilakukan sebagai bagian dari serangan yang meluas atau sistematik yang diketahuinya bahwa serangan tersebut ditujukan secara langsung terhadap penduduk sipil....Lih UU Peradilan HAM no 26 tahun 2000.

10 Hal ini dimuat secara jelas dalam pasal 9 UU Peradilan HAM No 26 tahun 2000, yang menyatakan, Kejahatan terhadap Kemanusiaan sebagaimana dimaksud dalam Pasal 7 huruf b adalah salah satu perbuatan yang dilakukan sebagai bagian dari serangan yang meluas atau sistematik yang diketahuinya bahwa serangan tersebut ditujukan secara langsung terhadap penduduk sipil......dalam penjelasan pasal 9 dinyatakan, yang dimaksud dengan "serangan yang ditujukan secara langsung terhadap penduduk sipil" adalah suatu rangkaian perbuatan yang dilakukan terhadap penduduk sipil sebagai kelanjutan kebijakan penguasa atau kebijakan yang berhubungan dengan organisasi. Peryataan yang sama juga ditemukan dalam statuta Roma yang mencoba menjelaskan tentang "luas atau sistematik" dengan penegasan "Serangan yang ditujukan terhadap suatu kelompok penduduk sipil" berarti serangkaian perbuatan yang mencakup pelaksanaan berganda....sesuai dengan atau sebagai kelanjutan dari kebijakan negara atau organisasi untuk melakukan serangan tersebut (pasal 7 ayat 2.a) Sayangnya peryataan bahwa serangan sebagai kelanjutan dari sebuah kebijakan secara efektif berarti bahwa tindakan kejahatan tersebut haruslah sistematik. Statuta juga mensyaratkan adanya "aksi individual yang berkaitan dengan serangan" menimbulkan bahwa sugesti bahwa pelaku individual haruslah mengerti tentang kebijakan yang bersangkutan, untuk bias dinyatakan bersalah.Persyaratan ini merupakan kemunduran dan itu yang banyak menggagalkan kasus pelanggaran berat HAM untuk maju ke Peradilan HAM. Lih Statuta Roma, Mahkamah Pidana International, Elsam, Mei 2000.
} 
khususnya pada beberapa jajaran yang mengambil putusan.

Kelihatannya memang tidak mudah, apalagi dengan sikap yang ditunjukkan oleh petinggi TNI, selalu saja baku dan prosedural. Jawaban maupun peryataan yang dikemukakan dalam tiap sidang, akan berujung pada mereka yang berada di lapangan, yang berarti aparat bawahan. Perbuatan pelanggaran berat HAM akan selalu ditunjuk sebagai penyelewengan atas perintah dan akan sulit untuk bisa dikaitkan dengan jajaran atas. Jenjang operasi militer yang biasanya cenderung hirerakhis dan garis komandonya jelas, ketika dihadapkan pada pertanggung-jawaban atas pelanggaran berat HAM, akan menemui kemacetan. Ini berarti menyiratkan tiga ketentuan penting yang ada dalam garis komando, pertama keputusan tertinggi memang berada pada pimpinan karena posisi serta wewenangnya memungkinkan untuk menetapkan itu semua. Kedua, keputusan maupun ketetapan itu kemudian secara operasional diterjemahkan pada tingkat bawah, yang kemudian secara taktis akan diterjemahkan pada jenjang lebih bawah lagi hingga pada jajaran di lapangan. Ketiga kalau terjadi penyelewengan pada tingkat lapangan dalam pelaksanaan tekhnisnya, hal ini harus dipandang sebagai kekeliruan atau penyelewengan perorangan. Mereka-yang melakukan penyelewengan ini-harus dipandang secara orang-perorangan dan tidak bisa digeneralisasi sebagai representasi dari institusi TNI ${ }^{12}$. Ketentuan ini semua yang kemudian berujung pada banyaknya vonis dalam peradilan militer yang selalu saja menempatkan bawahan sebagai 'terhukum' dalam tiap pelanggaran berat HAM, sebagaimana terlihat dalam vonis kasus penembakan empat mahasiswa Tri Sakti, seperti yang tertera pada tabel di bawah ini.

\begin{tabular}{|l|c|c|}
\hline \multicolumn{1}{|c|}{ Terdakwa } & Tuntutan & Vonis \\
\hline Iptu Erick Kadir Sully & 3 tahun & 6 tahun \\
\hline Briptu Raul de Costa & 2,5 thun & 4 tahun \\
\hline Bharatu Suparwanto & 2 tahun & 3 tahun \\
\hline Briptu Joko Irwanto & 2 tahun & 4,5 tahun \\
\hline Briptu Teddy Iskandar & 2 tahun & 4,5 tahun \\
\hline Briptu Anang Yulianto & 2 tahun & 4,5 tahun \\
\hline Briptu Cahyo Nugroho & 2 tahun & 4,5 tahun \\
\hline Bharatu Langgeng Sugiarto & 2 tahun & 3 tahun \\
\hline Bharatu Santosa & 1,5 tahun & 3 tahun \\
\hline
\end{tabular}

Catatan: Selain hukuman penjara kesembilan terdakwa juga dipecat dari anggota Brimob ${ }^{12}$

Padahal dalam UU Peradilan HAM disebut secara tegas, bahwa pelaksanaan pada tingkat tekhnis bukan semata-mata kesalahan operasional melainkan juga melibatkan tanggung jawab komando. Tertera dalam pasal 42 UU Peradilan HAM, ${ }^{13}$ bahwa kejelasan dan eksplisitnya suatu perintah yang mengandung unsur

"Lih Kleden, Ignas., 2001, "Argumentasi sang Jenderal", dalam, Menulis Politik; Indonesia sebagai Utopia, Kompas.

${ }^{12}$ Lih Kompas 1-2-2002.

${ }^{13}$ Pasal 42 menyatakan pada ayat 1 Komandan Militer atau seseorang yang secara efektif bertindak sebagai komandan militer dapat dipertanggung-jawabkan terhadap tindak pidana yang berada dalam yurisdiksi Pengadilan HAM, yang dilakukan pasukan yang berada di bawah komando dan pengendalianya efektif, atau di bawah kekuasaan dan pengendaliannya yang efektif dan tindak pidana tersebut merupakan akibat dari tidak dilakukan pengendalian pasukan secara patut........kemudian juga dalam ayat 2 dinyatakan seorang atasan, baik polisi maupun sipil lainnya (a) atasan tersebut mengetahui atau secara sadar mengabaikan informasi yang secara jelas menunjukkan bahwa bawahan sedang melakukan atau barú saja melakukan pelanggaran hak asasi manusia yang berat, dan (b) atasan tersebut tidak mengambil tindakan yang layak dan diperlukan dalam ruang lingkup kewenanganya untuk mencegah atau menghentikan perbuatan tersebut atau menyerahkan pelakunya kepada pejabat yang berwenang untuk dilakukan penyelidikan, penyidikan dan penuntutan....Lih UU Peradilan HAM no 26 tahun 2000. 
pelanggaran HAM cukup dipandang sebagai bagian dari pelanggaran HAM. Bahkan kalau dalam pelaksanaan tekhnis operasional di lapangan, komandan yang mengetahui bahwa terjadi pelanggaran HAM dan membiarkannya, itupun dipandang sebagai sebuah pelanggaran. Karena memang untuk dinyatakan sebagai pelanggaran HAM, jika mengikuti kaidah International, bukan saja bentuknya suatu perbuatan tetapi juga pembiaran yang kesemuanya disalahkan kepada negara sekaligus aparaturnya. ${ }^{14}$ Itu sebabnya dalam pelanggaran berat HAM jelas komandan militer mengambil tanggung jawab terbesar, karena memang kita semua tahu, bahwa garis komando militer selalu berjalan dari atas ke bawah. Bisa diandaikan pula bahwa suatu perintah, apapun bentuknya, cukup menjamin tanggung jawab komandan di dalamnya. Sehingga dalam pelanggaran HAM tidak dikenal penyelewengan yang dilakukan oleh prajurit tekhnis di lapangan, karena ketentuan ini, berpijak dari pembinaan maupun kultur yang ada di tubuh Militer. Di mana setiap organisasi militer dimanapun keberadaanya, akan mengikuti pola yang cenderung seragam, yakni struktur hierarki yang ketat. Hanya dalam militer sajalah terdapat ketentuan baku, yakni asas yang berbunyi, Gehorsamkeit ist blinde Gehorsamkeit (taat berarti taat secara buta).

Dalam kenyataannya, kita banyak tahu, wewenang pimpinan TNI terhadap bawahannya memang sangat luas. Kultur dalam TNI sendiri selalu membedakan secara tajam antara kesalahan individual dengan kesalahan institusi. Institusi TNI yang terlanjur dipandang sebagai kekuatan sosial-politik yang memiliki jasa besar tidak memberi kemungkinan untuk terjatuh dalam kesalahan apalagi penyelewengan. Dengan mengklaim bahwa semua pelanggaran HAM merupakan kesalahan anak buah, TNI kelihatan sebagai organisasi, yang tertinggal arus besar demokrasi dan keterbukaan. Dalam bahasa Wiranto hal ini termuat dalam peryataannya yang mengatakan; selama bawahan bertindak disiplin dan berprestasi, mereka adalah bagian dari institusi, dan pada saat mereka menyeleweng dan melakukan pelanggaran HAM, mereka adalah bagian orangperorangan. Etika keorganisasian yang terbelakang ini akan menjerumuskan TNI dalam budaya organisasi yang melatih para anggotanya untuk menerapkan ABS (asal bapak senang) dan ABB (asal bapak benar) Dengan kultur ini maka, yang timbul adalah serangkaian patologi yang cenderung menghambat proses penegakan HAM. Pertama, sistem dalam TNI sendiri akan makin cenderung tertutup dan tidak mau dikontrol. Dengan kondisi seperti ini, TNI akan menjadi institusi yang cenderung tidak apresiatif pada beberapa wacana yang penting, seperti Hak Asasi Manusia. Padahal dalam instrumen HAM sangat ditekankan bagaimana melatih dan menegakkan disiplin satuan militer agar bertindak secara bermartabat dan manusiawi. Misalnya dalam penggunaan senjata maupun penanganan aksi massa

14 Pelanggaran HAM menurut Deklarasi Prinsip Dasar Kejahatan Perang \& Penyalahgunaan Kekuasaan, terdiri dari dua aspek: Pertama, Suatu pelanggaran hukum pidana yang berlaku dalam suatu negara, termasuk hukum yang melarang penyalahgunaan wewenang Pidana. Pusat perhatian dalam pelanggaran ini adalah kerugian perorangan atau kelompok dan penderitaan yang diakibatkan terhadap orang, termasuk luka fisik atau mental, penderitaan emosional, kerugian ekonomi atau sangat melemahnya hak dasar mereka, karena tindakan atau tiadanya tindakan yang dapat disalahkan kepada Negara; Kedua tindakan atau tiadanya tindakan (yang disalahkan kepada negara) yang belum merupakan pelanggaran hukum pidana nasional tetapi merupakan norma yang diakui secara International terkait dengan Hak Asasi Manusia. 
dalam terminologi HAM terdapat berbagai ketentuan yang rinci dan penting. Akibat diabaikannya prinsip-prinsip HAM, TNI akan menjadi kekuatan yang berbahaya di masa depan, khususnya dalam penegakan sistem sosial masyarakat yang lebih demokratis.

Patologi kedua yang tidak kalah rawanya, arus pertanggung-jawaban yang terhenti pada aparat lapangan akan menyebabkan timbulnya sistem yang berwatak otoriter dan represif. Kondisi ini akan memperburuk institusi TNI sendiri, karena hubungan antara atasan dan bawahan bukan berdasar atas kerja-sama atau kemitraan tetapi loyalitas yang buta. Dengan demikian yang diutamakan dan dihargai adalah bawahan yang selalu berbuat sesuai dengan keinginan atasan, bukan sesuai dengan visi dan misi organisasi. Atasan ini bukan semata-mata mereka yang ada dalam lingkungan TNI, tetapi juga atasan, adalah mereka yang memiliki kedudukan yang berpengaruh. Bahaya yang lazim pada sistem ini, adalah lepasnya tali komando, karena bisa jadi pasukan lapangan akan dimintai order oleh pihak lain. Sebagaimana kasus pembunuhan Theys yang diidentifikasi sebagai pertarungan antar mantan pimpinan TNI yang kebetulan jadi 'beking' dari sektor usaha yang sama. Tentu ini hanya contoh, terdapat banyak kasus yang serupa seperti, pembunuhan terhadap Marsinah, penculikan mahasiswa dan pemenjaraan berbagai kelompok oposisi. Sedangkan patologi ketiga, jika kenyataanya hanya prajurit lapangan yang harus bertanggung-jawab ini akan menghadapkan masyarakat sipil dengan elemen dalam TNI sendiri, yang kebetulan sejajar dalam posisi kelas sosialnya. Yang kita tahu, posisi prajurit lapangan ini amatlah lemah, selain karena gajinya yang rendah, jaminan sosialnya yang kecil juga pendidikannya yang terbatas. ${ }^{15}$ Sedangkan korban dari pelanggaran berat HAM juga berada pada posisi kelas sosial yang sama, miskin dan tidak mungkin membalas jika dianiaya.

Prajurit TNI di lapangan yang kondisinya memprihatinkan ini makin teraniaya ketika harus bertanggung jawab 'sendirian' dalam pelanggaran HAM. Buat petinggi TNI, yang memegang garis komando, dengan kehidupan yang cukup makmur, tentu punya banyak cara untuk lolos dari hukuman. Yang agak khas memang dalam kehidupan hukum di negeri ini, adalah sulitnya untuk menjerat para pelanggar hukum yang memiliki kekuasaan ekonomi dan pengaruh politik yang besar. Dan mengenakan hukuman hanya pada prajurit lapangan tentu tidak akan menyelesaikan persoalan pelanggaran berat HAM yang merupakan agenda besar reformasi. Jika dibiarkan kecenderungan mengorbankan 'bawahan' ini akan merambat pula pada institusi lain, seperti Polisi, yang juga rentan pada pelanggaran HAM. Ironisnya terdapat banyak aturan International, yang memberikan perlindungan pada bawahan, jika menolak perintah atasan yang jelas mengandung

\footnotetext{
${ }^{15}$ Kasus yang terjadi di Polda Kalbar, untuk seorang anggota bintara polisi saja, syarat untuk masuk 'ketika ditetapkan nilai rata-rata 5 sangat sedikit yang bisa tertampung, tapi ketika diturunkan rata-rata 3,5 terdapat ledakan jumlah pendaftar. Anggota bintara yang kelak bertugas di lapangan ini merupakan penegak hukum jalanan, apa jadinya dengan nilai rata-rata yang sangat rendah ini terhadap kualitas pelayanan hokum. Belum jika ditilik motif mengapa masuk jadi Polisi, yang kebanyakan semata-mata karena butuh pekerjaan, belum didasari oleh keinginan untuk menegakkan hukum. Kondisi ini makin diperparah oleh gaji rendah yang diperoleh dan jaminan yang memprihatinkan. Ringkasnya aparat lapangan, hampir selalu jadi 'contoh buruk, dari perlakuan sistem terhadap bawahan. Lih Kompas, Penegak Hukum dengan Nem 3,5, 24 April 2002.
} 
unsur pelanggaran HAM. ${ }^{16}$ Aturan ini yang tertuang dalam Prinsip-prinsip dasar tentang Tentang Penggunaan Kekerasan dan Senjata Api oleh Aparatur Penegak Hukum, secara jelas memberikan perlindungan sekaligus menyatakan pemihakan pada aparat lapangan yang menolak perintah yang melanggar HAM. Memang aturan ini, dalam standar International berbentuk soft law, yang tidak memiliki kekuatan mengikat secara hukum. Aturan ini dituangkan agar menjadi 'ilham' atau 'model' bagi suatu negara yang ingin mengatur aparat penegak hukumnya.

Persoalannya memang terpulang pada sejauh mana budaya penegakan HAM sudah terumuskan dalam institusi TNI. Artinya, diperlukan budaya kelembagaan dimana masing-masing aparat mampu menjalankan tugas secara, reasonable (dan karena itu tidak menimbulkan kontradiksi) dan acceptable (dan karena itu tidak menimbulkan resistensi, apalagi oposisi) Melalui perumusan kebudayaan organisasi yang menghargai nilai-nilai HAM ini, di masa depan TNI, akan memberikan sumbangan bagi terumuskannya sistem kelembagaan yang demokratis. Usaha untuk ini dapat dikerjakan, mulai dengan pembubaran berbagai institusi keamanan yang memiliki reputasi dalam pelanggaran HAM, seperti Kopassus. Gagasan dibubarkanya Kopassus ini sama dengan kebijakan untuk dihapus-kanya Bakorstanas (Badan Bantuan Koordinasi
Stabilitas Nasional) yang memiliki kepanjangan tangan di daerah, yakni Bakorstanada yang telah dihapus oleh Abdurrahman Wahid pada minggu pertama Maret 200o. Lembaga ini kedudukanya sama dengan dua lembaga represif lain, yakni Opsus (Operasi Khusus) dan Kopkamtib (Komando Operasi Pemulihan Keamanan dan Ketertiban) yang juga telah dihilangkan. Kebijakan untuk penghapusan ini perlu ditindak-lanjuti, selain untuk memper-tautkan budaya organisasi TNI dengan perkembangan dinamis instrumen HAM juga merupakan keharusan bagi sebuah organisasi yang ingin menanam kembali kepercayaanya pada rakyat. Meskipun, di sisi lain, gagasan ini tentu akan ditentang oleh sebagian besar kalangan dan menjadi problematis pada saat bangsa ini masih punya persoalan berat tentang keamanan. Tetapi yang perlu kita ingat, memang sudah waktunya untuk mendorong TNI sebagai institusi yang tunduk pada prinsip-prinsip HAM dan meninggalkan segala pendekatan yang bersifat represif. Dengan mengakui dan mendorong prinsip HAM dalam kultur TNI, kita akan mampu untuk merumuskan secara ulang dan bersama-sama, tentang apa itu ancaman, apa itu makna keamanan dan lebih mudah kita sebagai bangsa untuk menjelaskan kehadapan masyarakat International, arti tanggung jawab dalam makna Hak Asasi Manusia, yang kini telah diakui oleh semua negara di dunia.

${ }^{16}$ Dalam klausul Prosedur Lapangan dan Tinjauan, dinyatakan, (25) Pemerintahpemerintah dan badan-badan penegak hukum akan memastikan bahwa tidak ada sanksi pidana atau disiplin dikenakan pada aparatur penegak hukum, yang sesuai dengan kode etik Aparatur Penegak Hukum dan prinsip-prinsip dasar ini, menolak menjalankan suatu perintah untuk menggunakan kekerasan dan senjata api, atau yang melaporkan penggunaan hal-hal tersebut oleh para petugas lainnya (26) Kepatuhan kepada perintah atasan bukan merupakan pembelaan kalau pejabat penegak hukum tahu bahwa suatu perintah untuk menggunakan kekerasan dan senjata api mengakibatkan kematian atau terluka parahnya seseorang nyatanyata tidak sah dan mempunyai kesempatan yang cukup untuk menolak mengikuti perintah tersebut. Bagaimana pun juga, tanggung jawab juga terletak pada atasan yang memberi perintah tidak sah tersebut. Lih Prinsip-prinsip dasar tentang penggunaan kekerasan dan senjata api oleh aparatur penegak hukum. Disahkan di Havana, Kuba, 27 Agustus sampai 7 September 1990. 
Daripada TNI tetap bertahan dengan kultur yang lama, lalu dengan terpaksa diseret oleh Pengadilan International, sebagaimana yang kini dialami oleh kalangan Jenderal di Yugoslavia. Sukar sekali untuk berkelit dari makna tanggung jawab dalam sistem hukum HAM, dimana menurut ketentuannya, negara atau masyarakat international, bisa saja mengambil alih. Akibatnya, kejahatan HAM yang sekalipun terjadi di wilayah Indonesia, akan dapat diadili dan divonis oleh pengadilan International. Vonis yang kini sudah dijatuhkan pada Mayjen TNI Johny Lumintang yang didenda sebesar US\$ 66 juta atau sekitar 653 milliar pada akhir februari 2000 dan Mayor Jenderal Sintong Panjaitan yang bersalah atas kematian korban dalam tragedi Santa Cruz dengan denda US\$ 14 juta oleh pengadilan Amerika. ${ }^{17}$ Cara ini ditempuh karena memang sistem hukum HAM hendak memerangi impunity (kekebalan) yang kerapkali jadi alat berkelit kalangan petinggi TNI. Dalam kerangka inilah, maka tidak adil, jika hanya menempatkan aparat lapangan sebagai terhukum tunggal. Juga tidak adil jika untuk kejahatan kemanusiaan yang sepadan nilainya dengan harkat serta martabat manusia, dikecualikan vonis hukumnya, karena alasan membela kesatuan bangsa dan negara. Gerak pertanggung-jawaban dalam sistem hukum HAM yang makin menuju pada sistem komando, mendorong kalangan petinggi TNI, untuk tidak memiliki pihan lain kecuali mempertimbangkan dengan segala hal setiap keputusan yang ditetapkanya. Dalam praktek, persoalan pertanggung- jawaban ini memiliki implikasi yang luas, yakni pilihan untuk tindakan pengamanan harus mengutamakan nilai-nilai kemanusiaan dan karenanya setiap kebijakan yang diambil, harus memperhitungkan empat faktor penting. Yaitu, apakah tindakan yang diambil itu sesuai dengan hukum, kedua apakah tindakan itu proporsional, ketiga sesuaikah dengan etika, keempat memang tindakan itu diperlukan dan yang terakhir tindakan itu hendaknya bisa diterima oleh masyarakat. Keempat pertimbangan ini harus dijadikan pedoman, bahkan perlu dibuat dalam rumusan organisasi, sehingga tidak mendorong TNI kembali pada masa masa gelap.

\section{Kesimpulan}

Penulis kutip judul Menunggu Godot bukan tanpa maksud. Itu adalah lakon yang bagi orang Jepang, dipahami sebagai gambaran mengenai masa depan yang lebih baik. Menunggu Godot, semacam masa depan yang lebih baik, zaman yang tanpa tekanan dan masa dimana kebrengsekan akan musnah. Sedangkan di kalangan orang Jawa, Godot mungkin seperti Ratu Adil atau Satrio Piningit, yang didambakan kehadiranya. Ringkasnya Godot, mengacu pada keadaan menantikan sesuatu. ${ }^{18}$ Situasi penantian itu sangat terasa, bagi sekian banyak korban pelanggaran HAM, yang menunggu dan menanti vonis pada mereka yang telah mengambil peran-peran represif. Suasana pemerintahan pada masa Orde Baru, masih sangat terasa, dimana kekejaman hampir tanpa batas dan yang

17 Dua gugatan ini dimungkinkan karena pertama di Amerika ada UU Klaim Ganti Rugi atas Orang Asing tahun 1789, yang membolehkan warga non Amerika menggugat pelanggaran hukum Amerika atau hukum International yang terjadi di luar Amerika; kedua UU Perlindungan Korban Kekerasan tahun 1992 yang mengesahkan gugatan ke Pengadilan asalkan diserahkan di Amerika.

${ }^{18}$ Lih Bakdi Soemanto, Dari Beckett ke Rendra, Dari Godot ke Mini Kata,Jurnal Kebudayaan Kalam No 16. 
menakjubkan, tidak ada pelaku yang dihukum. Bagi banyak korban pelanggaran HAM, sikap menerima, pasrah dan cemas mungkin merupakan pilihan yang ada pada saat itu. Kini harapan itu muncul seketika, bukan semata-mata karena Soeharto jatuh, tetapi mencuatnya ide HAM yang bukan sekedar wacana. Dengan gagasan HAM yang menemukan rumusan konkretnya dalam bahasa hukum, kekuasaan yang represif dan sadis itu, jadi tampak rendah dan memalukan.

Di bawah rezim hukum Hak Asasi Manusia, kekebalan segolongan orang yang berpangkat, jadi luntur. Seperti tekanan yang mendidih, kekejaman yang dulu hanya selembar berita dan secuil kisah, kini mencoba untuk diangkat ke permukaan. Peradilan HAM yang konon akan mengadili dan memintai pertanggung-jawaban, mengambil fungsi yang tidak kalah bersejarah, mencatat kembali nama korban. Hampir seperti impian di Nuremberg, ketika para Jenderal Nazi, harus tunduk malu mengakui kesalahan. Mungkin seperti wajah para Jenderal di Afrika, yang memohon maaf karena pernah melakukan tindakan kejam pada penduduk. Kesalahan kadang bukan semata-mata faktor khilaf, lebih sering, kekejaman itu seperti sebuah rencana memasak. Prosesnya didahului oleh motif, yang selalu saja digambarkan secara abstrak, demi untuk membela persatuan, menjaga stabilitas, mencegah kerusuhan hingga mentaati perintah atasan. Tatkala kekejaman itu kemudian menghasilkan ratusan, ribuan bahkan jutaan korban tibatiba, komentar yang muncul, itu karena kesalahan prosedur. Enak memang menjadi penguasa, menempatkan korban seperti seutas buncis, yang tidak memiliki harga diri. Dengan memulai pendirian Peradilan HAM semua korban akan dapat duduk tegak, mengambil sikap dan berdiri tegas. Untuk mengatakan apa yang mereka memang masih ingat dan seperti yang dikatakan Jurgen Habermas, kekejaman buat korban adalah seperti sebatang bayangan tubuh. Kenangan itu hidup dan bisa diceritakan sedetail mungkin, ibarat sekotak layar TV yang membuka siaran, ketika dipencet tombolnya.

Tetapi pentas Peradilan HAM itu harus membuat kita sedikit tersenyum kecut. ${ }^{99}$ Di situ berlangsung lakon yang bahkan menempatkan sosok Jenderal yang tangannya berlumur darah, duduk sopan, rapi, gagah dan bahkan sempat memberikan ceramah pada majelis hakim. Ia mengatakan merebaknya jumlah korban itu bukan kesalahan TNI, bahkan TNI berusaha menjaga sebaik mungkin stabilitas. Ia tidak menyesal bahkan juga tidak kelihatan cemas, persis seperti tampang para penjagal Nazi, yang dengan lantang mengatakan segala pembunuhan itu merupakan tugas suci negara. Sepedih apapun, karya TNI pada beberapa peristiwa, harus dipandang sebagai lukisan kusam yang diperlukan bagi tegaknya sebuah republik. Dengan nada yang sama, beberapa Jenderal juga menyanyikan hymne serupa, lupakan yang lalu untuk

19 Keraguan akan efektifitas Peradilan HAM ini yang kemudian dinyatakan oleh gabungan berbagai organisasi nonpemerintah, yang terdiri atas Elsam, Judicial Watch, Kontras, LBH Jakarta, PBHI, SNB serta sejumlah Ornop lain yang menyatakan, bahwa Peradilan HAM untuk kasus Timor-Timur dan Tanjung Priok, belum memberikan orientasi yang jelas dalam hal penegakan HAM. Ini dapat dirujuk dari tidak adanya perangkat pendukung, seperti peraturan perlindungan saksi dan korban, peraturan tentang kompensasi, restitusi dan rehabilitasi bagi korban, serta komisi kebenaran dan rekonsiliasi dan kebenaran yang sampai saat ini hanya berhenti pada tingkar wacana. Kata aliansi Ornop, ini menimbulkan kesan kuat, Pengadilan HAM banyak diwarnai intervensi pemerintah yang sarat dengan kepentingan politik. Lih Kompas 30 Januari 2002. 
songsong masa depan. Peradilan HAM seperti deretan kisah sinetron, bermula dan berakhir, seperti yang diduga oleh masyarakat. Ilusi keadilan kembali menjadi asap, yang hanya patut diperdebatkan dalam ruangan diskusi tanpa butuh, kenyataan yang bisa dirasakan dan dinikmati. Kekejaman hendak dijadikan mimpi yang diwariskan pada semua generasi, lalu kitapun akan menyiarkan pada masyarakat International, kalau kita sudah memenuhi apa yang mereka inginkan. Harapan tentang keadilan, seperti rejeki buat rakyat kecil, jauh dan makin menjauh. Bukan semata-mata karena memang ringkihnya sistem peradilan tetapi masih kukuhnya lapisan yang menghendaki situasinya tetap seperti apa adanya. Apalagi mereka masih bisa duduk dalam kursi kekuasaan dan lihai dalam memberi pengaruh.

Tetapi risalah HAM bukan seperti aturan kampung, yang gampang diubah, melainkan ketentuan hukum yang digerakkan dan diawasi oleh masyarakat International. Karena itu Slobodan Milosevic, harus diseret secara paksa oleh pasukan PBB dan ditempatkan dalam posisi sebagai tersangka di pengadilan Den Hagg. Sistem hukum HAM bekerja dengan jangkauan serta dukungan dari banyak negara, yang mulai membenci, tindakan kekejaman tetapi kebal oleh hukuman. Sistem hukum HAM memang dibuat, untuk memburu para penjahat kemanusiaan, yang berlindung di balik nasionalisme dan kedaulatan sebuah negara. Sistem itu menyatakan berhak intervensi jika negara memang tidak mampu memberikan hukuman setimpal bagi setiap pelanggaran berat HAM. Untuk menghidupkan sistem ini maka berbagai ketentuan dan lembaga diciptakan. Untuk membuat sistem ini dipatuhi maka berbagai sanksi sengaja dibuat agar memang negara tidak lagi mampu berkelit dan membikin-bikin alasan. Itu sebabnya muncul ancaman Asia Pacific Forum (APF) for Human Right terhadap keanggotaan Komnas HAM karena tidak independennya badan ini dalam kedudukannya di UU No 39/1999. Ringkasnya sistem ini memang berusaha menjebol dinding pertahanan setiap negara, yang melakukan kekejaman tetapi mencari perlindungan dengan sistem hukum nasionalnya. Meskipun masih adanya banyak upaya untuk mensiasati aturan, yang sesekali dilakukan oleh negara tertentu, tetapi namanya pelanggar HAM saat ini tidak bisa dengan senyum bangga, menyatakan akan mampu lolos dari kekejaman yang ia kerjakan. Gerak TNI yang selalu berlindung di bawah payung alat keamanan negara sekalipun, tidak akan bisa aman, dengan makin diakuinya pemberlakuan sistem hukum Hak Asasi Manusia. Kekuatannya bahkan kini berpengaruh, pada saat mana, posisi negara ini sangat suram dan makin tergantung pada uluran bantuan hutang. Sistem hukum HAM bagaimanapun, adalah ketetapan hukum, yang mencoba untuk meletakkan prinsip kemanusiaan sebagai budaya yang mustinya sejak semula, ada pada aparat serta institusi keamanan di semua negara.

\section{Daftar Pustaka}

Prasetyo, Eko. 2001. HAM Kejahatan Negara \& Imperialisme Modal, Yogyakarta: Insist Press \& Pustaka Pelajar.

Kleden Ignas. 2001. Menulis Politik Indonesia Sebagai Utopia, Jakarta, Kompas. Howard, Rhoda E 1995. Penjelajahan Dalih Relativisme Budaya, Jakarta: Grafiti, Yayasan Adikarya IKAPI dan Ford Foundation.

Thiam Hien, Yap. 1998. Negara, HAM \& Demokrasi, Jakarta: YLBHI

Ifdhal Kasim (ed). 2000. Dimensi-dimensi HAM pada Administrasi Kedilan, Jakarta: Elsam.

Ifdhal Kasim (ed). 1995. Hak Sipil dan Politik: Esai-esai Pilihan, Jakarta: Elsam 
'Menunggu Godot', Peradilan HAM dan Tanggung Jawab TNI

Nadj, E Sobirin dan Mardinah Nining (ed). 20oo. Diseminasi Hak Asasi Manusia, Jakarta: Cesda dan LP3 ES.

Sciortino, Rosalia. 1999. Menuju Kesehatan Madani, Yogyakarta: Pustaka Pelajar.

Ifdhal Kasim (pengant). 2000. Statuta Roma Mahkamah Pidana International, Jakarta: Elsam.

C. de Rover, C.de. 1999 To Serve \& to Protect Acuan Universal Penegakan HAM, Jakarta: Rajawali Press.

Nickel, James W. 1996. Hak Asasi Manusia, Refleksi Filosofis atas Deklarasi Universal Hak Asasi Manusia, Jakarta: PT Gramedia Pustaka Utama
Surat Kabar dan Majalah

Jurnal Kalam (Jakarta)No 172001

Tempo (Jakarta)

Edisi 29 November-5 Desember 1999

Edisi 30 Okoter-5 November 2000

Edisi 12-18 Juni 2000

Edisi 12-18 Maret 2001

Edisi 5-11 Maret 2001

Kompas (Jakarta)

25 April 2001

3 Mei 20001

12 April 2001

9 Agustus 2000

4 Juli 2001

10 Juli 2001

19 Juli 2001

21 Juli 2001

24 Juli 2001

27 Juli 2001

Suar (Komnas HAM)

10 Mei 2001

Desember 2000 